セリシン加工スポーツウェアが人体生理および疲労抑制に及ぼす影響

\author{
富山大学人間発達科学部諸岡晴美 \\ セーレン（株）＼cjkstart不破順清・長田勝栄 \\ 奈良女子大学生活環境学部 諸岡英雄
}

\title{
Effects of Sericin Processed Sportswear on Physiological Response and Fatigue.
}

\author{
Harumi Morooka ${ }^{* 1}$, Naozumi Fuwa ${ }^{* 2}$, Katsue Osada ${ }^{* 2}$ and Hideo Morooka $^{* 3}$ \\ ${ }^{* 1}$ Faculty of Human Development, Toyama University, 3190, Gofuku, Toyama 930-8555, Japan \\ ${ }^{* 2}$ SEIREN Co., Ltd., 10-1, Keya 1 Chome, Fukui 918-8560, Japan \\ ${ }^{*}$ Faculty of Life and Environment, Nara Women's University, Kita-uoya Nishi-machi, \\ Nara 630-8506, Japan
}

\begin{abstract}
Wear experiments were conducted to examine clothing temperature $\left(\mathrm{T}_{\mathrm{cl}}\right)$, clothing humidity $\left(\mathrm{H}_{\mathrm{cl}}\right)$, oral temperature $\left(\mathrm{T}_{\mathrm{co}}\right)$, sweat rate $(\mathrm{SW})$, heart rate $(\mathrm{HR})$, subjective feelings, and body reaction time. A Kraepelin test was performed using a sericin processed sportswear and a regular one as a control.

1. The sericin processed garment had lower values of $T_{c o}, H R$ and $S W$ than the regular one. From these results, it was considered that subjects that were wearing the sericin processed garment would have a lower physiological load than subjects of the regular garment.

2. From the correlation analysis, it was found that $\mathrm{H}_{\mathrm{cl}}$ is a very important factor in the results mentioned above. That is, it was considered that sericin processed on wear makes the moisture and water performance of the wear increase, and then the wear can make sweat evaporate smoothly. Further, the smooth evaporation can reduce the $\mathrm{H}_{\mathrm{cl}}$, consequently, the lower $\mathrm{H}_{\mathrm{cl}}$ can restrain the $\mathrm{T}_{\mathrm{co}}$, $\mathrm{HR}$ and SW. Because this tendency was remarkable during and just after exercise, it was suggested that the sericin processed wear is useful when sweating.
\end{abstract}

3. Subjects who wore the sericin processed wear felt lower fatigue. However, the results of the reaction time and Kraepelin test were not significant statistically.

(Received 21 June, 2005 ; Accepted 22 September, 2005)

\section{1. 緒 言}

虫（Bombyx mori）が吐き出すシルクは，フィブロイン というたんぱく質の周囲をセリシンが覆った構造となっ ている1). シルクを用いた加工については, 諸岡らが疎水 性である PVCレザーにシルクの微粉末を配合することに よって吸湿性が高まり使用性能が向上したと報告してい る2!.また，フィブロインのみを用いた綿の防しわ加工に 関する研究もみられる3 ${ }^{3,4}$ 。一方, シルクを衣料素材とし て利用する場合, その独特の光沢や風合いを生み出すた めに, セリシンは不要成分として除去され, 廃棄されて きた。フィブロインは衣料素材の有効成分であるため,
できれば廃棄成分を利用することが環境面からも望まし いと考えられる. 近年, シルクの精練廃液からセリシン を回収する技術が確立し5), また，セリシンが優れた保湿 性(6) と抗酸化作用)を有することが明らかになってきてい る.

本研究では, セリシンを定着させたスポーツウェアを 用いた着用実験を行い，運動中および運動前後の衣服内 温湿度, 生理反応としての口腔温, 発汗量, 心拍数の測 定および主観評価を行った。また，疲労の指標として全 身反応測定およびクレペリン検査を行い, セリシン加工 ウェアの人体生理および疲労抑制に及ぼす影響を明らか にすることを目的として行った. 


\section{2. 実験方法}

\section{1 実験用ウェア}

実験用ウェアとして，市販のスポーツウェア上衣（半 そで丸首シャツ，ポリエステル $94 \%$ ／ポリウレタン $6 \%$ ) および下衣（8 分丈ズボン，ポリエステル $83 \%$ /ポリウ レタン $17 \%$ ）の表面にセリシン加工を施したものと，コ ントロールとしてレギュラー品を用いた。

\section{2 セリシン加工法}

セリシン加工法については，三宅らによって生系から セリシンを分離回収した高分子量のセリシンを他の加工 剂を併用することなく繊維に定着させたという報告がみ られるが8)，本報では以下のようにして加工を行った。セ

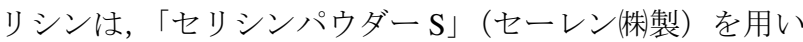
た. セリシン加工前に, 市販のスポーツウェアに付着し ている繊維加工剂や污れを落とすため， $0.1 \%$ ポリオキシ エチレンオレイルエーテル $60^{\circ} \mathrm{C}$ で 20 分間, 浴比 $1: 30$ の 条件で洗浄し, 水で充分す寸いだ後脱水し, 室内乾燥し た.

セリシン加工は， $1.3 \%$ セリシンパウダー S, $1.3 \%$ ポリ エチレングリコールジグリシジルエーテル， $0.05 \%$ ジエチ レントリアミンの水溶液を調製し, 洗浄後のスポーツウェ ア上衣・下衣を浴比 $1: 20$ で浸漬した. 次にピックアップ 率 75〜80\% となるようにマングルで脱水処理し, $100^{\circ} \mathrm{C}$ で 10 分間乾燥, $160^{\circ} \mathrm{C}$ で 30 秒間キュアリングを行った. さらに $80^{\circ} \mathrm{C}$ で 10 分間湯洗後，水で充分す寸ぎ， $100^{\circ} \mathrm{C}$ で 10 分間乾燥した。 セリシン付着量は， $1.3 \%$ の水溶液の 75 〜 $80 \%$ ピックアップで約 $1 \%$ 付与となるが，ドライキュ ア後の洗浄で 10〜20\% 脱落し，最終的には試料重量あた り約 $0.8 \% \sim 0.9 \%$ であった。なお，セリシンの定着は強 固であり，30 回洗濯後も $80 \%$ 以上の残存量であることを 確認している.

\section{3 加エウェアの厚さ，重さと水分特性}

レギュラーおよび加工布の厚さ，重さを表 1 に，SEM 写真を図 1 に示寸。厚さに大きな違いはみられないが, 重さは加工布で約 $10 \%$ 程度重くなっている。これは，若 干の収縮が生じたためと考えられる。また，SEM写真か らはセリシンが㵶維表面に付着している様子がわかる. また，水分特性として，吸湿性（水分率）および吸水性 （吸水面積）の測定を行った。吸湿性については，標準 状態 $\left(20^{\circ} \mathrm{C} 65 \% \mathrm{RH}\right)$ に加え， $20^{\circ} \mathrm{C} 93 \% \mathrm{RH}$ の高湿状態で の水分率を測定した。吸水性は，アクリル板上にマイク

Table 1 Thickness and weight of samples.

\begin{tabular}{c|c|c|c}
\hline \multicolumn{2}{c|}{ Wear } & $\begin{array}{c}\text { Thickness } \\
(\mathrm{mm})\end{array}$ & $\begin{array}{c}\text { Weight } \\
\left(\mathrm{g} / \mathrm{m}^{2}\right)\end{array}$ \\
\hline \multirow{2}{*}{ Upper } & Regular & 0.63 & 237 \\
& Processed & 0.61 & 256 \\
\hline \multirow{2}{*}{ Lower } & Regular & 0.56 & 219 \\
& Processed & 0.60 & 243 \\
\hline
\end{tabular}

$※$ at a pressure of $49 \mathrm{~Pa}$

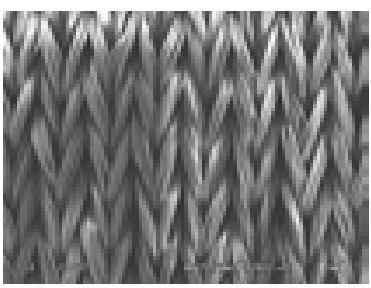

$(\times 40)$

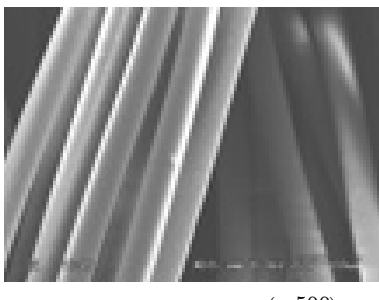

$(\times 500)$ (a) Regular (b) Processed

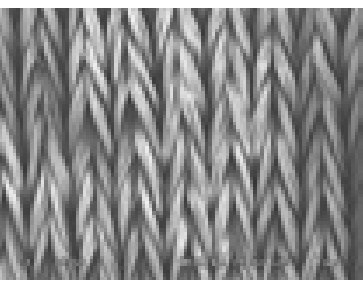

$(\times 40)$

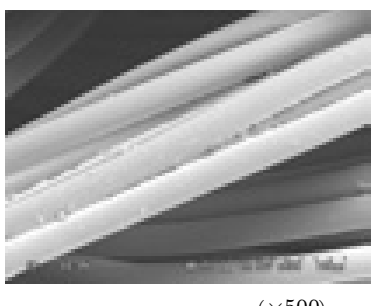

$(\times 500)$
Fig. 1 SEM micrographs of Regular fabric (a) and Processed fabric (b).
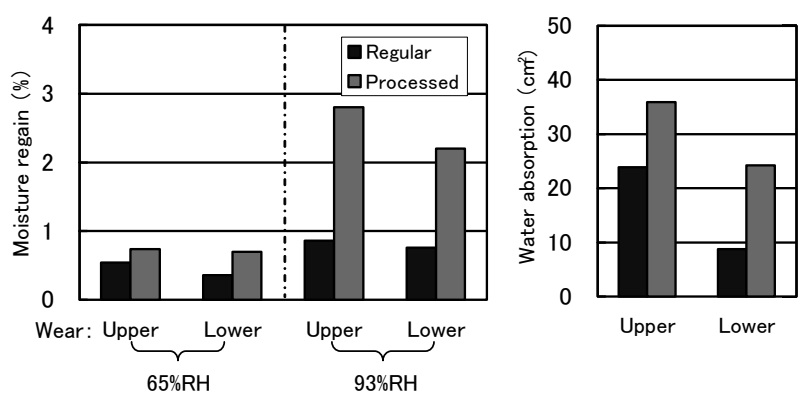

Fig. 2 Moisture regain (under $20^{\circ} \mathrm{C} 65 \% \mathrm{RH}$ and $20^{\circ} \mathrm{C}$ 93\% RH) and water absorption of samples.

ロシリンジで蒸留水を $0.3 \mathrm{ml}$ 滴下し，その上に試料を設置 し 5 分後の吸水面積を測定した。結果を図 2 に示す。上 衣・下衣ともにセリシン加工により吸湿性・吸水性の向 上がみられたが，特に高湿時における水分率の向上が顕 著であった。

\section{4 被験者}

表 2 に示す年齢 $20 \sim 24$ 歳, 身長 $161.1 \pm 5.8 \mathrm{~cm}$, 体重 49.5 $\pm 4.2 \mathrm{~kg}$ の体型をもつ健康な成人女性 7 名を被験者とし, レギュラー着用（以後，単にレギュラーとする） 2 回，加 工着用（以後，単に加工とする） 3 回の実験を 1 人 1 日 1 回として，計 5 日間行った.

セリシン加工下着が，アレルギー疾患の皮膚症状に対 して改善効果があったとの報告から ${ }^{91}$ ，皮膚になんらかの 影響を及ぼし持続的な生理変化がある可能性を考慮して,

Table 2 Physical characteristics of subjects.

\begin{tabular}{c|rrrrr}
\hline Subject & \multicolumn{1}{|l}{ Age } & \multicolumn{1}{c}{$\begin{array}{l}\text { Hight } \\
(\mathrm{cm})\end{array}$} & $\begin{array}{c}\text { Weight } \\
(\mathrm{kg})\end{array}$ & $\begin{array}{c}\text { Body fat } \\
(\%)\end{array}$ & \multicolumn{1}{c}{ BMI } \\
\hline $\bar{X}$ & 21.4 & 161.1 & 49.5 & 21.1 & 19.1 \\
$\sigma$ & 1.3 & 5.8 & 4.2 & 2.5 & 1.6 \\
Max. & 24.0 & 172.0 & 55.4 & 24.8 & 21.6 \\
Min. & 20.0 & 153.0 & 44.0 & 18.5 & 17.3 \\
\hline
\end{tabular}
※ BMI :Weight $(\mathrm{kg}) \div$ Height $(\mathrm{m})^{2}$ 


\begin{tabular}{|c|c|c|c|c|c|c|c|c|c|c|}
\hline \multicolumn{2}{|c|}{$\begin{array}{c}\text { Evaluation } \\
\downarrow\end{array}$} & \multicolumn{9}{|c|}{$\begin{array}{c}\text { Evaluation } \\
\qquad\end{array}$} \\
\hline \multirow{2}{*}{ )Wearing } & \multirow{2}{*}{$\begin{array}{l}\text { Reacting time \& } \\
\text { Kraepelin test }\end{array}$} & \multirow{2}{*}{$\begin{array}{c}\text { Sensors } \\
\text { begin }\end{array}$} & \multirow{2}{*}{ Rest } & \multicolumn{3}{|c|}{ Exercise (walking) } & \multirow{2}{*}{ Rest } & \multirow{2}{*}{$\begin{array}{c}\text { Sensors } \\
\text { end }\end{array}$} & \multirow{2}{*}{\begin{tabular}{|c|} 
Walking \\
$8 \mathrm{~km} / \mathrm{h}$
\end{tabular}} & \multirow{2}{*}{$\begin{array}{c}\text { Reacting time \& } \\
\text { Kraepelin test }\end{array}$} \\
\hline & & & & $5.5 \mathrm{~km} / \mathrm{h}$ & $7.5 \mathrm{~km} / \mathrm{h}$ & $8 \mathrm{~km} / \mathrm{h}$ & & & & \\
\hline \multicolumn{3}{|l|}{ \# } & 5 & 3 & 5 & \begin{tabular}{|l|}
2 \\
\end{tabular} & 15 & & 5 & \\
\hline
\end{tabular}

Fig. 3 Protocol.

着用順序をランダムとはせず，はじめにレギュラーを 2 日間，その後セリシン加工を 3 日間連続で実験を行うこ ととした。なお，性周期や日内リズムによる影響を考慮 して低体温期とし，被験者ごとに同一時間帯でかつ食後 2 時間以上経過していることとした.

\section{5 測定項目}

生理量としてロ腔温, 発汗量, 心拍数（R-R 間隔）の 測定, 主観評価として温冷感, 湿潤感, 快適感, 疲労感 の 4 項目, 疲労の指標として全身反応時間およびクレペ リン検查を行った。また，皮膚と実験用ウェアとの間の 衣服内温度および衣服内湿度の測定を行った。

\section{6 測定手順}

実験期間を平成 16 年 8 月中旬〜9月中旬とした。プロ トコルを図 3 に示す。被験者は実験室 $\left(27.7 \pm 0.1^{\circ} \mathrm{C}, 58.3\right.$ $\pm 1.1 \% \mathrm{RH} ）$ に入室後, 十分に実験環境に慣れさせた後, 実験用ウェアに着替えて, 椅座安静状態において 1 回目 の主観評価を行った. その後, 全身反応時間の測定とク レペリン検查を行った後, 各測定用センサーを被験者に 貼付した. 実験は, 5 分間椅座安静 (以後, 実験前とする) -10 分間歩行運動 $(3$ 分間 $5.5 \mathrm{~km} / \mathrm{h}, 5$ 分間 $7.5 \mathrm{~km} / \mathrm{h}, 2$ 分 間 $8 \mathrm{~km} / \mathrm{h}$. 以後, 運動中とする) -15 分間椅座安静（以 後, 回復期とする）とし，この間の計 30 分間の口腔温, 発汗量, 心拍数 (R-R 間隔) および衣服内温湿度の測定 を行った。運動直後に2 回目の主観評価を行い, 測定を 一旦終了し, 各種センサーをできるだけ迅速に取りはず した，その後，再び疲労度を上げるために歩行運動（5 分 間 $8 \mathrm{~km} / \mathrm{h}$ ) を行った後に, 全身反応時間の測定とクレペリ ン検査を行った。

口腔温 (舌下温) は, 精度 $\pm 0.1^{\circ} \mathrm{C}$ の熱電対型温度セン サーを用い, インターバル 2 秒で測定した。発汗量は, 連続蒸散・発汗測定装置 $(K \& S$ (株製) を用い, 背部と左 大腿前面（以後, 脚部とする）にセンサーを貼付し，イ ンターバル 2 秒で測定した。 心拍数は, Polar バンテージ $\mathrm{NV}$ ハートレートモニター (キャノントレーディング(株) 製）を用い，インターバル 2 秒で測定した R-R 間隔から 算出した。衣服内温湿度は，背部と脚部に精度 $\pm 0.5^{\circ} \mathrm{C}, 2$ $\% \mathrm{RH}$ のセンサーを貼付し，インターバル 2 秒で測定した。 主観評価は, 温冷感 (7 段階), 湿潤感 (5 段階), 快適感 (4 段階), 疲労感 (4 段階) について行わせた. 全身反 応時間は, 全身反応測定器 II 型（竹井機器工業(株製）を 用い, 光 (赤) 刺激に対する反応時間（光を認識してか ら垂直飛びによりマットから足が離れるまでの時間）を 3 回練習した後に測定を 5 回行わせた.クレペリン検査は, 連続加算作業 1 分間を 5 回, 寸なわち 5 分間行わせた.

\section{3. 結果および考察}

結果は，レギュラーについては実験 14 回（=着用実験 2 回×被験者数 7 人), 加工については実験 21 回（=着用 実験 3 回 $\times$ 被験者数 7 人) の平均值を用いて解析を行っ た. なお, 平均值の差の検定はスチューデントの $\mathrm{t}$ 検定 を用いて行った。

\section{1 生理量および衣服内温湿度の変化挙動}

レギュラー着用時の各測定值 $X_{R}$ から加工着用時の各測 定值 $X_{P}$ を差し引いた $\Delta X \quad\left(=X_{R}-X_{P}\right)$ を 5 分ごとに 平均した值および $\Delta X$ の最大值とそれが生じた実験時間 を表 3 に示す。また, 口腔温 $\mathrm{T}_{\mathrm{co}}$, 発汗量 $\mathrm{SW}$, 衣服内湿度 $\mathrm{H}_{\mathrm{cl}}$ の変化挙動を図 4 , 図 5 , 図 6 に示す.

口腔温 $\mathrm{T}_{\mathrm{co}}$ (図 4) は, 加工・レギュラーともに運動に よる代謝産熱の増大により運動開始後緩やかに上昇し, 運動中期の歩行速度の増加により急速に上昇した。運動 停止後も持続的な代謝六進と強制対流の停止により $\mathrm{T}_{\mathrm{co}}$ は さらに上昇し, そのまま平衡を保ち, 実験終了時までほ とんど回復しなかった。このような $\mathrm{T}_{\mathrm{co}}$ の変化は運動によ る生理的メカニズムによるものであるため, 両ウェアは ほぼ同様の挙動を示したものと推察される. しかし, ウェ アにより $\mathrm{T}_{\mathrm{co}}$ 值には相違が認められ，加工はレギュラーよ り全般的に $\mathrm{T}_{\text {co }}$ が低く, 運動時〜運動停止直後に最大 0.09 ${ }^{\circ} \mathrm{C}, 5$ 分平均では $0.06-0.05^{\circ} \mathrm{C}$ 低い傾向がみられた。 心拍 数 HR は, 運動によって筋組織への酸素の需要が高まる ために, 運動開始後即座に上昇し, 歩行速度が増加する たびにさらに上昇し, 約 160beat/min にまで達した。運動 後期〜回復期にかけての両ウェアの HR の相違が大きく, 加工はレギュラーに比べて最大で 3.5 拍, 5 分間平均では 1.9-2.6 beat/min 低い傾向がみられた。

Table 3 The mean values of the difference between the processed wear and the regular wear were calculated every five minutes.

\begin{tabular}{|c|c|c|c|c|c|c|c|c|}
\hline \multicolumn{2}{|c|}{ Term } & \multicolumn{6}{|c|}{$\Delta X=X_{R}-X_{P}$} & \multirow{2}{*}{$\begin{array}{c}\text { Max.(Time) } \\
0.09 \text { (6min.) }\end{array}$} \\
\hline $\mathrm{Tc0}$ & $\left({ }^{\circ} \mathrm{C}\right)$ & 0.04 & 0.06 & \begin{tabular}{|l|}
0.05 \\
\end{tabular} & 0.05 & 0.02 & -0.01 & \\
\hline $\mathrm{HR}$ & (1/min.) & -1.3 & -0.1 & 1.9 & 2.6 & 2.2 & 2.2 & 3.5 (21min.) \\
\hline SW & Back & 0.07 & 0.05 & 0.09 & 0.07 & -0.03 & -0.02 & 0.11 (13min.) \\
\hline$\left(\mathrm{mg} / \mathrm{cm}^{2}\right)$ & Leg & 0.04 & 0.05 & 0.18 & 0.16 & 0.05 & 0.03 & 0.21 (14min.) \\
\hline $\mathrm{Tcl}$ & Back & -0.08 & 0.01 & 0.08 & -0.07 & 0.02 & 0.14 & 0.21 (11min.) \\
\hline$\left({ }^{\circ} \mathrm{C}\right)$ & Leg & -0.02 & -0.07 & -0.13 & -0.06 & -0.06 & 0.00 & $-0.22(14 \mathrm{~min})$. \\
\hline $\mathrm{Hcl}$ & Back & 2.2 & 1.7 & 5.1 & 3.1 & 5.7 & 6.7 & 7.1 (28min.) \\
\hline (YRH) & Leg & 0.4 & -0.3 & 3.8 & 1.3 & 2.0 & 2.1 & 5.2 (11min.) \\
\hline \multirow{2}{*}{\multicolumn{2}{|c|}{$\begin{array}{l}\text { Experimental time } \\
(\text { min. })\end{array}$}} & $0-5$ & $6-10$ & $11-15$ & $16-20$ & $21-25$ & $26-30$ & \\
\hline & & Rest & \multicolumn{2}{|c|}{\begin{tabular}{l|} 
Exercise \\
\end{tabular}} & \multicolumn{3}{|c|}{ Rest } & \\
\hline
\end{tabular}

$X r$ and $X p$ denote the experimental values in wearing the regular garment and processed garment, respectively. 


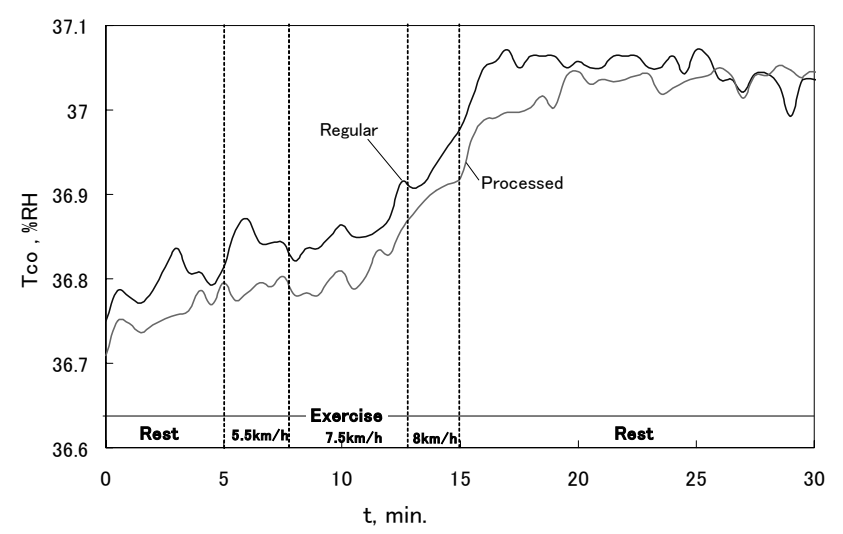

Fig. 4 The changes in oral temperature $\mathrm{T}_{\mathrm{co}}$.

発汗量 SW（図 5）は，実験が夏季であったため，発汗 潜伏期が短く, 運動開始約 2 分以後から発汗量が急激に 増大した. 運動中〜運動直後の $\mathrm{SW}$ の挙動は $\mathrm{T}_{\mathrm{co}}$ と類似し ていた.このことは, 深部温を恒温に維持しようとする 自律性体温調節として発汗が促進されたことを示唆する ものであり， $\mathrm{T}_{\mathrm{co}}$ の高かったレギュラーで $\mathrm{SW}$ が大きく， $\mathrm{T}_{\mathrm{co}}$ の上昇が小さかった加工で $\mathrm{SW}$ が小さい傾向がみられ, 運動後期には最大で $0.11 \mathrm{mg} / \mathrm{cm}^{2}$ (背部)， $0.21 \mathrm{mg} / \mathrm{cm}^{2}$ (脚 部）の差がみられた。

衣服内温度 $\mathrm{T}_{\mathrm{cl}}$ は, 両ウェアともに運動開始後に強制対 流により歩行速度の上昇とともに低下し, 運動終了直前 には, 背部で約 $0.7^{\circ} \mathrm{C}$, 脚部で約 $1.0^{\circ} \mathrm{C}$ 低下した。 また, 運動終了後は強制対流の停止により約 $1.5^{\circ} \mathrm{C}$ 急速に上昇す る傾向がみられた。これらの変動に比べて両ウェア間の 相違は小さかった。衣服内湿度 $\mathrm{H}_{\mathrm{cl}}$ (図 6) は, 発汗量 $\mathrm{SW}$ が上昇し始める時間（図 5 参照）とほぼ同時刻に上昇し 始めるなど, SW の変化とほぼ同様の挙動を示した。また, SW の高かった未加工 (背) > 加工 (背) >未加工 (脚部) $>$ 加工 (脚部) の順に $\mathrm{H}_{\mathrm{cl}}$ が高い傾向がみられた。また, 運動後半および回復期後半で両ウェアの相違が大きく, 加工はレギュラーに比べて最大で $7.1 \%$ (背部)， $5.2 \%$ (脚 部）低い傾向がみられた。

\section{2 衣服内温湿度と各生理量間の関係}

被験者 7 名の加工およびレギュラーについての衣服内 温湿度, 各生理量の 1 分ごとのデータを用いて運動前, 運動中, 回復期に分けて測定項目間の関係をみるために

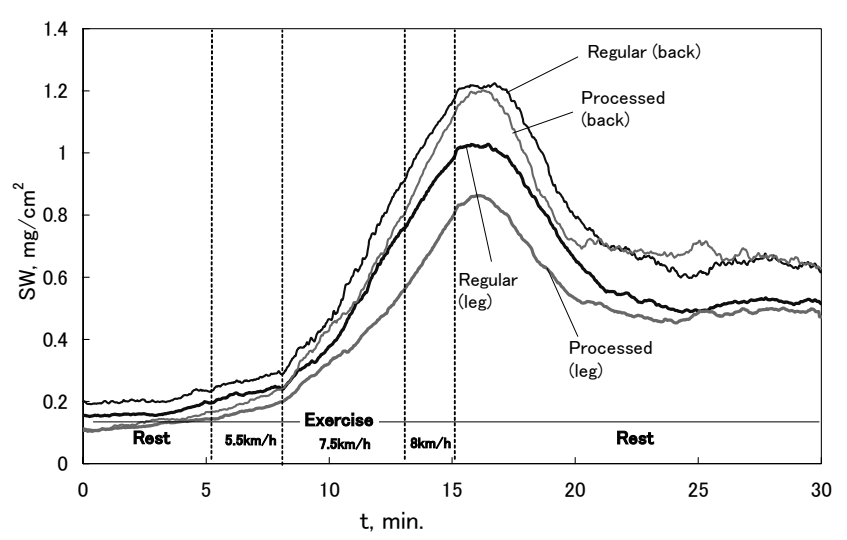

Fig. 5 The changes in sweat rate SW.

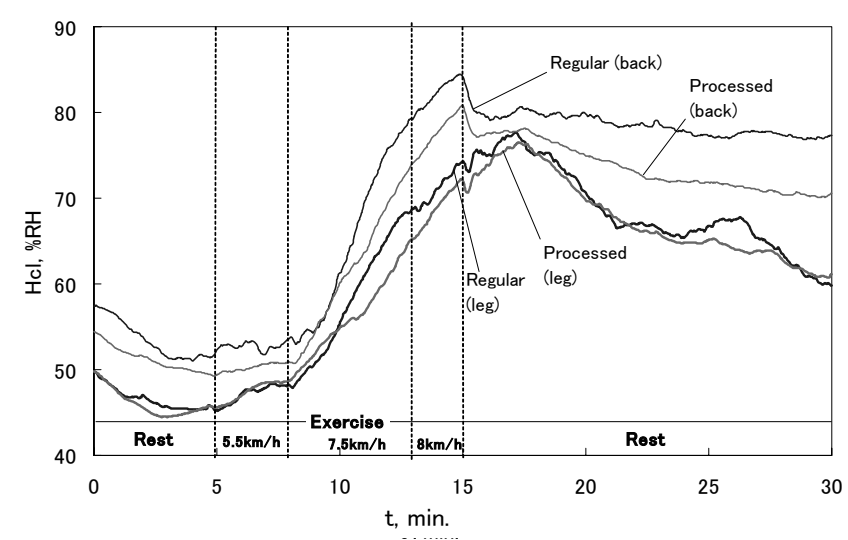

Fig. 6 The changes in clothing humidity $\mathrm{H}_{\mathrm{cl}}$.

相関分析を行った．データ数は各々 $70,140,210$ である 結果を表 4 に示す. まず背部について $r>0.5$ （表中に太字 で表示）をみると, 運動前では $\mathrm{T}_{\mathrm{co}}$ と $\mathrm{HR}$ との間に, 運動 中では $\mathrm{HR}$ と $\mathrm{SW}, \mathrm{H}_{\mathrm{cl}}$ と $\mathrm{SW}, \mathrm{H}_{\mathrm{cl}}$ と $\mathrm{HR}$ との間に, 回復 期では $\mathrm{SW}$ と $\mathrm{H}_{\mathrm{cl}}$ との間に正の相関がみられた。脚部にお いては, 運動前安静時において $\mathrm{T}_{\mathrm{cl}}$ と $\mathrm{T}_{\mathrm{co}}, \mathrm{T}_{\mathrm{cl}}$ と $\mathrm{HR}$ との 相関がみられたが, 運動中においては $\mathrm{T}_{\mathrm{cl}}$ と生理量との関 係は小さくなり， $\mathrm{H}_{\mathrm{cl}}$ との相関が高くなるなど背部とほぼ 同様の傾向がみられた。これらの各測定項目間の相関関 係はヒトの自律性体温調節の観点から以下のように考察 することができる.

運動を開始すると, 骨格筋等の末梢組織の産熱量が急 増するために酸素の需要が高まり, 心拍数が増加する.

また, 産熱の増大により $\mathrm{T}_{\mathrm{co}}$ が上昇傾向を示す. 恒体温を 維持するためには, 放熱を促進する必要があり, 皮膚血 流量が増加し, さらには発汗する. 運動開始初期のこの 変化挙動は生理的メカニズムによるものであるため, こ の期間のウェア間の相違は小さい. 発汗後, 着用してい るウェアが汗を迅速に外界に放出しなければ $\mathrm{H}_{\mathrm{cl}}$ が上昇す る. $\mathrm{H}_{\mathrm{cl}}$ が上昇すると皮膚からの直接の潜熱放散が減少し, 深部体温である $\mathrm{T}_{\mathrm{co}}$ が上昇する. $\mathrm{T}_{\mathrm{co}}$ が上昇すると, 顕熱 放散を促進するために血管拡張が生じ一回拍出量が減少 し ${ }^{10)}$ ，HR が増大するとともに SW がさらに増大するとい うフィードバックに繋がる.このことは, $\mathrm{T}_{\mathrm{co}}, \mathrm{HR}, \mathrm{SW}$ の生理量において特に発汗量が多い運動後半および運動 停止直後で両ウェアの相違が大きく, $\Delta X$ の最大值もほ とんどが運動中であったことからも裏付けられる（表 3 参照). 寸なわち, セリシン加工ウェアを着用した場合, $\mathrm{H}_{\mathrm{cl}}$ の上昇が抑制されたことが， SW の抑制と HR の上昇 抑制に繋がったと考えられる。また，回復期においても $\mathrm{H}_{\mathrm{cl}}$ と SW との間に有意な相関がみられたもののその相関 係数は低く, 運動前では $\mathrm{H}_{\mathrm{cl}}$ との関係はみられなかった. このことは, セリシン加工の効果が発汗時で有効である ことを示唆するものである.

セリシン加工ウェアは, 吸湿・吸水性が向上したこと, 特に高湿時の吸湿性の増大が大きかったことが汗を迅速 にウェアに吸着し衣服内湿度を低下させたと推察され, このことが発汗時においてレギュラーより人体の生理的 負荷を低下させたものと考えられる. 
Table 4 Correlation coefficients between clothing climate and physiological values.

\begin{tabular}{|c|c|c|c|c|c|c|c|c|c|}
\hline & \multicolumn{4}{|c|}{ Back } & \multicolumn{4}{|c|}{ Leg } \\
\hline & & $\mathrm{T}_{\mathrm{co}}$ & SW & HR & $\mathrm{T}_{\mathrm{cl}}$ & $\mathrm{T}_{\mathrm{co}}$ & SW & $\mathrm{HR}$ & $\mathrm{T}_{\mathrm{cl}}$ \\
\hline \multirow{4}{*}{$\begin{array}{c}\text { Rest } \\
\text { (before) }\end{array}$} & SW & 0.158 & & & & 0.157 & & & \\
\hline & $\mathrm{HR}$ & 0.734 * & * 0.282 * & & & 0.734 * & 0.126 & & \\
\hline & $\mathrm{T}_{\mathrm{cl}}$ & $0.471 *$ & 0.048 & 0.308 * & & $0.701^{* *}$ & 0.147 & 0.806 & \\
\hline & $\mathrm{H}_{\mathrm{cl}}$ & -0.125 & -0.072 & 0.006 & -0.713 & -0.425 ** & 0.174 & -0.378 & ${ }^{* *}-0.431$ ** \\
\hline \multirow{4}{*}{$\begin{array}{c}\text { During } \\
\text { (exercise) }\end{array}$} & $\mathrm{SW}$ & 0.268 * & & & & $0.307 *$ & & & \\
\hline & HR & 0.215 * & 0.792 ** & & & 0.215 * & 0.675 & & \\
\hline & $\mathrm{T}_{\mathrm{cl}}$ & 0.408 * & $=0.270$ ** & -0.352 & & $0.443^{* *}$ & -0.276 & $*-0.364$ & \\
\hline & $\mathrm{H}_{\mathrm{cl}}$ & 0.143 & $0.774^{* *}$ & 0.817 & $*-0.529$ & 0.122 & 0.781 & 0.852 & ${ }^{* *}-0.4333^{* *}$ \\
\hline \multirow{4}{*}{$\begin{array}{c}\text { Rest } \\
\text { (recovery) }\end{array}$} & SW & 0.327 * & & & & $0.244^{* *}$ & & & \\
\hline & $\mathrm{HR}$ & 0.277 * & * 0.345 ** & & & 0.277 * & 0.261 & & \\
\hline & $\mathrm{T}_{\mathrm{cl}}$ & 0.308 * & -0.045 & -0.319 * & & 0.143 * & -0.171 & ${ }^{*}-0.034$ & \\
\hline & $\mathrm{H}_{\mathrm{cl}}$ & 0.206 * & ${ }^{*} 0.5511^{* *}$ & 0.246 & 0.051 & 0.225 * * & 0.490 & *t* 0.213 & ${ }^{* * *}-0.2811^{* *}$ \\
\hline
\end{tabular}

\section{3 主観評価}

結果を表 5 に示す. 点数が高いほど, 暑い, べたつい ている, 不快, 疲れていることを示す. 実験前に比べて 実験後にはどの項目も点数が高くなった. 温冷感, 湿潤 感, 快適感においては両ウェアの差はみられなかった。 しかし, 疲労感では実験後に加工の方が危険率 5\% で有 意に疲労度が低いと評価され, 前述のレギュラーにおけ る生理量負荷が少なからず影響を及ぼしたものと推察さ れる。

Table 5 Subjective feeling.

\begin{tabular}{|c|c|c|c|c|c|c|c|c|}
\hline \multirow{3}{*}{ Sample } & \multicolumn{8}{|c|}{ Subjective Feeling } \\
\hline & \multicolumn{2}{|c|}{ Thermal } & \multicolumn{2}{|c|}{ Humid } & \multicolumn{2}{|c|}{ Comfort } & \multicolumn{2}{|c|}{ Fatigue } \\
\hline & Before & After & Before & After & Before & After & Before & After \\
\hline Regular & $4.6 \pm 0.79$ & $6.9 \pm 0.19$ & $2.9 \pm 0.56$ & $4.8 \pm 0.27$ & $1.4 \pm 0.34$ & $3.1 \pm 0.45$ & $1.4 \pm 0.48$ & $2.6 \pm 0.24$ \\
\hline Processed & $4.4 \pm 0.37$ & $6.9 \pm 0.16$ & $3.0 \pm 0.51$ & $4.9 \pm 0.16$ & $1.2 \pm 0.32$ & $3.0 \pm 0.33$ & $1.4 \pm 0.40$ & $2.3 \pm 0.51$ \\
\hline
\end{tabular}

\section{4 全身反応時間およびクレペリン検査}

全身反応時間およびクレペリン検查においては，個人 の運動神経や計算能力の相違が大きいため, 被験者ごと に実験前後の変化率 $\Delta Y\left(=100\left(Y-Y_{0}\right) / Y_{0}\right)$ を算出した. ここで， $Y$ は実験後の值， $Y_{0}$ は実験前の值を示す．その 結果, 被験者平均では, 全身反応時間の $\Delta Y$ は両ウェア ともに実験後に反応時間が短くなった. また, その傾向 はレギュラーで大きかった。 クレペリン検査においても, 両ウェアともに実験後に解答数が増加し, その傾向はレ ギュラーで大きかった. 実験後にむしろ成績が向上した 理由については, 疲労以上に鍛鍊の効果が大きかったた めと考えられる. また, 加工に比べてレギュラーで実験 後に成績が向上したことについても, 鍛錬の効果が初期 でより大きいことによるものと推察される.一方, 疲労 により作業効率が不安定になることが指摘されている ${ }^{11}$. そこで，全身反応時間およびクレペリン各々の測定回数 5 回の平均值 (レギュラー $\overline{Y_{0}}$, 加工 $\bar{Y}$ ) と標準偏差 $\sigma$ を用 いて変動率 $\mathrm{CV}\left(=100 \sigma / \overline{Y_{0}},=100 \sigma / \bar{Y}\right)$ を求めて解析し たが，やはり両ウェアの相違はみられなかった。しかし， 実験後に作業効率が低下したケースが約半数みられ, 検 討した結果（図 7), 加工はレギュラーに比べて值がやや 小さく, 作業効率の不安定性が少ない傾向がみられた.
しかし，統計的に有意ではなかった。このように全身反 応時間がクレペリン検查において両ウェアの相違を明確 にできなかった理由の一つとして,本研究での運動負荷が 小さかったことがあげられ，これについては今後の課題 としたい.

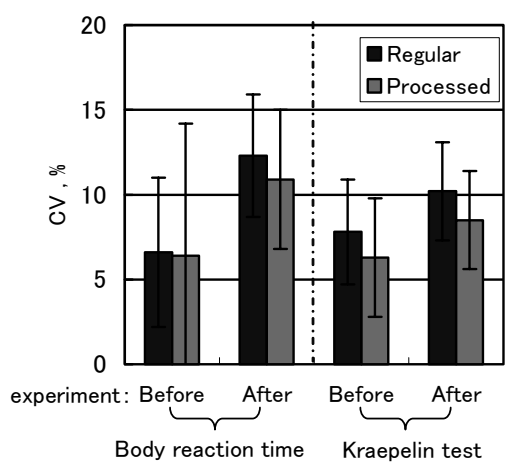

Fig. 7 Coefficients of variations in the reaction time and Kreapelin test.

\section{4. 結 語}

運動中および運動前後の衣服内温度 $\mathrm{T}_{\mathrm{cl}}$, 衣服内湿度 $\mathrm{H}_{\mathrm{cl}}$, 口腔温 $\mathrm{T}_{\mathrm{co}}$, 発汗量 $\mathrm{SW}$ および心拍数 $\mathrm{HR}$ の測定, 主観的 な着用感評価, 全身反応測定およびクレペリン検査から, セリシン加工スポーツウェアの人体生理および疲労抑制 への影響を明らかにすることを目的として行った。

加工ウェアはレギュラーに比べて, $\mathrm{T}_{\mathrm{co}}, \mathrm{HR}, \mathrm{SW}$ が低 く生理的負荷が小さいと判断された。また, 測定項目間 の相関分析により， $\mathrm{H}_{\mathrm{cl}}$ が重要な因子であることがわかっ た. すなわち, ウェアにセリシンを定着させることによ り, ウェアの吸湿性および吸水性が向上し, 汗の円滑な 蒸発により $\mathrm{H}_{\mathrm{cl}}$ が低下したことが $\mathrm{T}_{\mathrm{co}}, \mathrm{HR}, \mathrm{SW}$ の上昇を 抑制したと推察された. なお,この傾向が特に運動後半 および運動停止直後において大きかったことから，セリ シン加工ウェアは発汗時に有効であることが示唆された.

また, 主観評価では, 加工ウェア着用時の疲労度が有 意に低かったが，疲労の指標として測定した全身反応時 間およびクレペリン検查におけるウェア間の相違は認め られなかった。

\section{文 献}

1. M. Minagawa, "Kinu no Kagaku”, Kansai Iseikatsu Kenkyukai, 29-31 (1982).

2. Y. Yamauchi, H. Morooka et al., Sen'i Gakkaishi, 58, 202208 (2002).

3. Y. Kawahara, Sen'i Gakkaishi, 52, $562-565$ (1996).

4. Y. Kawahara, Sen'i Gakkaishi, 54, 122-125 (1998).

5. M. Nomura and H. Yamada, Sen'i Gakkaishi, 48, 305 (1992).

6. R. Voegeli et al., Cosmetics \& Toiletries, 108, 101 (1993).

7. N. Katoh, S. Satoh, A. Yamanaka, H. Yamada, N. Fuwa, 
and M. Nomura, Biosci. Biotechnol. Biochem., 62, 145 (1998).

8. H. Miyake, S. Yamashita, et al., Sen'i Gakkaishi, 60, 271275 (2004).

9. A. Shoji, A. Inoue, et al., Hifu, 41, 481-491 (1999).
10. S. Nakano, S. Shigeta, "Zusetsu Karada no Jiten”, p.351, Asakura shoten (1992).

11. S. Nakano, S. Shigeta, “Zusetsu Karada no Jiten”, p. 388, Asakura shoten (1992). 